\title{
Current and emerging "at-site" pain medications: a review
}

\author{
This article was published in the following Dove Press journal: \\ Journal of Pain Research \\ 7 September 2011 \\ Number of times this article has been viewed
}

\section{Praveen PN Rao \\ Tarek Mohamed \\ School of Pharmacy, Health Sciences Campus, University of Waterloo, Waterloo, ON, Canada}

\begin{abstract}
The myriad pain pathophysiology has intrigued and challenged humanity for centuries. In this regard, the traditional pain therapies such as opioids and nonsteroidal antiinflammatory drugs have been highly successful in treating acute and chronic pain. However, their drawback includes adverse events such as psychotropic effects, addiction potential, and gastrointestinal toxicities, to mention a few. These factors combined with the likelihood of an increase in chronic pain conditions due to an aging population calls for the development of novel mechanism-based or "site-specific" agents to target novel pain pathways. In this regard, rapid progress has been made in understanding the molecular mechanisms of novel pain targets such as cannabinoid receptors, fatty acid hydrolase, voltage-gated and ligand-gated ion channels such as $\mathrm{P} 2$ receptors, transient receptor potential channels and glial cell modulators. Accordingly, preclinical studies indicate that the site-specific/selective agents exhibit sufficient efficacy and reduced side effects such as lack of psychotropic effects indicating their clinical potential. This review provides a brief summary of some "at-site" pain targets and their role in the pain pathophysiology, and describes the efforts in developing some small molecules as novel pain therapeutics.
\end{abstract}

Keywords: opioids, nonsteroidal anti-inflammatory drugs, cannabinoid receptors, P2X receptors, transient receptor potential channels, glial cells

\section{Introduction}

The word "pain" is simple, yet complex. The quest of humans to conquer pain by investigating the underlying cause is a challenging and ongoing process. According to the International Association for the Study of Pain, the definition of pain as "an unpleasant sensory and emotional experience associated with actual or potential tissue damage, or described in terms of such damage" indicates the subjective nature of pain. ${ }^{1}$ It is the most common complaint for which patients seek medical attention, lose productivity, and incur health care costs. ${ }^{2}$ The epidemic status of pain across the globe is highlighted by a recent study which showed that nearly $37.3 \%$ and $41.1 \%$ of the adult population in the developed and developing countries, respectively, experience chronic pain due to diseases or disorders or injuries. ${ }^{3}$ Pain is characterized by both physical and psychological symptoms. Based on clinical characteristics, pain can be classified as nociceptive, neuropathic, or psychogenic/idiopathic. ${ }^{2,4-6}$ The mechanical, chemical, or thermal stimulation of peripheral sensory nerves due to surgery or trauma in a well localized area is described as nociceptive pain, whereas neuropathic pain is defined as an abnormal signaling resulting from injury or dysfunction of the peripheral or central nervous system (CNS) leading to pain. In addition, the latter is less localized and can
Correspondence: Praveen PN Rao School of Pharmacy, Health Sciences Campus, University of Waterloo, 200 University Ave W, Waterloo, ON N2L 3GI, Canada

Tel + I 5198884567 ext 21317

$\mathrm{Fax}+\mathrm{I} 5198887292$

Email praopera@uwaterloo.ca 


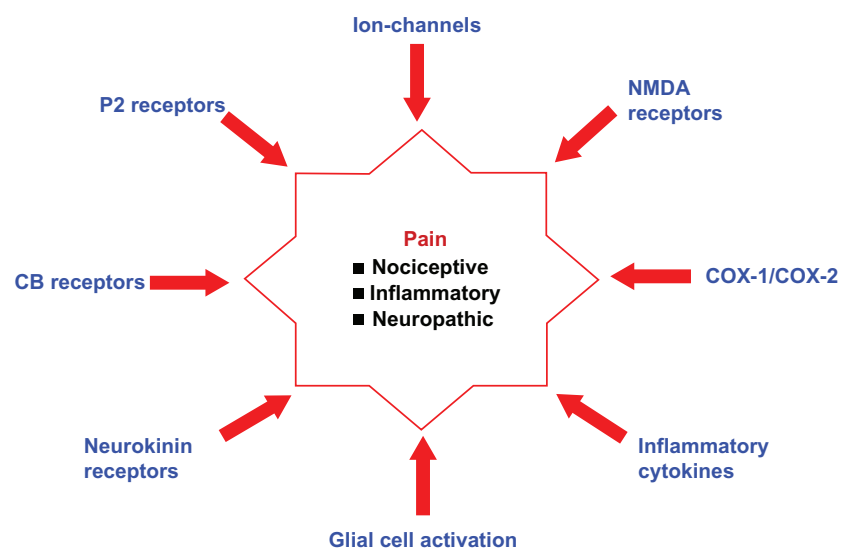

Figure I Summary of pain pathophysiology and some pain targets.

Abbreviations: $C B$, cannabinoid; COX, cyclooxygenase; NMDA, N-MethylD-aspartate.

persist in the absence of visible injury or inflammation. ${ }^{7-11}$ Pain perception/assessment in patients with personality disorders, mood disorders, or substance abuse indicates the influence of psychiatric disorders on pain etiology. ${ }^{12,13}$ Traditional pain-management therapies involve analgesics such as acetaminophen and aspirin, nonsteroidal anti-inflammatory drugs (NSAIDs) such as ibuprofen and indomethacin, and narcotics such as morphine. ${ }^{14,15}$ However, there is a growing concern on the risks of overdose, abuse, and addiction potential of these agents. For example, in the United States alone,<smiles>CCCCCCCc1cc(O)c2c(c1)OC(C)(C)C1CCC(C)=CC21</smiles>

(1) $K_{i}=39.5 \mathrm{nM}\left(\mathrm{CB}_{1}\right) ; 40.0 \mathrm{nM}\left(\mathrm{CB}_{2}\right)$<smiles>CC(C)(C)c1ccc([C@H]2C[C@H](O)CC[C@H]2CCCO)c(O)c1</smiles>

(3) $K_{i}=0.6 \mathrm{nM}\left(\mathrm{CB}_{1}\right) ; 0.7 \mathrm{nM}\left(\mathrm{CB}_{2}\right)$

Figure 2 Chemical structures of some nonselective $C B$ receptor modulators. Abbreviations: $C B$, cannabinoid; $K$, inhibition constant. about 30,000 hospitalizations are attributed to acetaminophen overdose, whereas NSAID therapy is associated with fatal gastrointestinal bleeding and potential cardiovascular risks. ${ }^{16-18}$ In addition, narcotic analgesic abuse and addiction is a serious concern. ${ }^{19}$ These facts mandate the need to look beyond traditional pain targets such as cyclooxygenases and opioid receptors. The complexity in understanding the pain mechanisms listed in Figure 1 will go a long way in developing new therapies. Current research efforts are ongoing to discover agents with superior efficacy and safety profiles that target novel pathological routes as pain therapeutics (Figure 1). Emerging pain targets include cannabinoid (CB) receptors, fatty acid amide hydrolase (FAAH), voltage- and ligand-gated ion channels (sodium channels, T-type calcium channels, N-type calcium channels, P2 receptors, transient receptor potential [TRP] channels), peptide receptor antagonists, nerve growth factor (NGF), and glial cell modulators. This review describes recent developments in the discovery of $\mathrm{CB}_{2}$ agonists, TRP vanilloid-1 (TRPV1) channel antagonists, $\mathrm{P} 2$ receptor antagonists, and agents that target activated glia.

\section{The CB receptors}

The CB receptors are part of the endocannabinoid system and are G-protein coupled receptors. Their role in the modulation of pain and inflammation is well documented..$^{20-22}$<smiles>CCCC(C)(C)c1cc(O)c2c(c1)OC(C)(C)C1CCC(CO)=CC21</smiles>

(2) $K_{i}=0.7 \mathrm{nM}\left(\mathrm{CB}_{1}\right) ; 0.2 \mathrm{nM}\left(\mathrm{CB}_{2}\right)$<smiles>Cc1c(C(=O)c2cccc3ccccc23)c2cccc3c2n1[C@@H](CN1CCOCC1)CO3</smiles>

(4) $K_{i}=1.9 \mathrm{nM}\left(\mathrm{CB}_{1}\right) ; 0.3 \mathrm{nM}\left(\mathrm{CB}_{2}\right)$ 
Mammalian tissues express two types of $\mathrm{CB}$ receptors: $\mathrm{CB}_{1}$ and $\mathrm{CB}_{2}$ respectively. $\mathrm{CB}_{1}$ receptors are primarily expressed in the $\mathrm{CNS}$, whereas $\mathrm{CB}_{2}$ receptors are primarily located in the periphery such as immune cells, spleen, and tonsils. ${ }^{23}$ In this regard, a number of $\mathrm{CB}$ receptor agonists were reported. The classic $\mathrm{CBs}$, tetrahydrocannabinol $\left(\Delta^{9}\right.$-THC, Marinol ${ }^{\circledR}$, Solvay Pharmaceuticals, Ixelles, Brussels, Belgium) (Figure 2, compound (1)) and dimethylheptyl tetrahydrocannabinol (HU-210) (Figure 2, compound (2)) based on a tricyclic terpenoid template are nonselective $\mathrm{CB}$ agonists with HU-210 exhibiting a greater degree of binding affinity toward $\mathrm{CB}$ receptors (Figure 2). The major drawback of classical CB therapy in pain management is the impairment of cognitive/motor function and altered psychological state. ${ }^{24,25}$ Compound CP-55,940 (Figure 2, compound (3)), a nonclassical $\mathrm{CB}$ was developed based on the chemical structure of $\Delta^{9}$-THC and played a major role in the discovery of the $\mathrm{CB}_{1}$ receptor. ${ }^{26}$ Consequently, the development of an aminoalkyl indole-based small molecule such as WIN55212 (Figure 2, compound (4)) provided some degree of $\mathrm{CB}_{2}$ selectivity. ${ }^{27}$ Eicosanoids such as anandamide ${ }^{22,28}$ represent endogenous $\mathrm{CBs}$ that exhibit greater affinity toward $\mathrm{CB}_{1}$ than $\mathrm{CB}_{2}$. Since centrally acting $\mathrm{CB}_{1}$ receptor agonists are known to produce CNS side effects such as dizziness and cognitive impairment, current focus is to develop $\mathrm{CB}_{2}$ receptor agonists that could produce minimal CNS side effects and to target $\mathrm{CB}_{1}$ receptors at the periphery. $22,29,30$

A number of small-molecule $\mathrm{CB}_{2}$ receptor agonists have been developed in the past decade as potential agents to treat nociceptive, inflammatory, and neuropathic pain. The mechanism of $\mathrm{CB}_{2}$-mediated analgesia is not clearly understood. Some studies suggest that $\mathrm{CB}_{2}$ agonists could act on immune cells and prevent the associated inflammatory response. A recent investigation by Hsieh and coworkers shows that the dorsal root ganglia and spinal cord regions are the potential sites of $\mathrm{CB}_{2}$-receptor-mediated analgesia. ${ }^{31} \mathrm{In}$ this regard, one of the early $\mathrm{CB}_{2}$-receptor agonists HU-308 (Figure 3, compound (5), a bicyclic derivative) exhibited high $\mathrm{CB}_{2}$ selectivity $\left(\mathrm{CB}_{2}\right.$ inhibition constant $\left.\left[K_{i}\right]=23 \mathrm{nM}\right)$ and significant pain relief in the formalin model. ${ }^{32}$

A wide range of small molecules with diverse ring templates have been developed as $\mathrm{CB}_{2}$-selective agonists (Figures 3, 4, and 5). In this regard, several aminoalkyl indolebased derivatives exhibit superior $\mathrm{CB}_{2}$ receptor binding and selectivity. ${ }^{33-36}$ For example, AM1241 (Figure 3, compound (6)) is a highly selective $\mathrm{CB}_{2}$-agonist $\left(\mathrm{CB}_{2} K_{i}=3.4 \mathrm{nM} ; \mathrm{CB}_{1}\right.$ $K_{i}=280 \mathrm{nM}$ ) that exhibits in vivo peripheral analgesia in inflammatory and neuropathic pain models without exhibiting

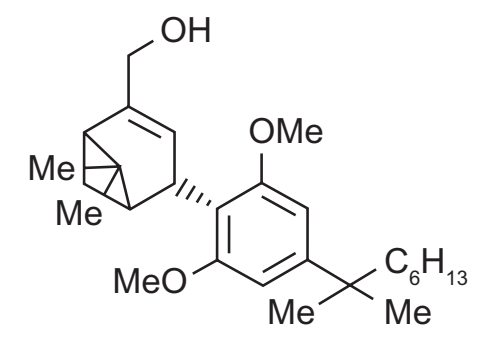

(5) $K_{i}>10 \mathrm{nM}\left(\mathrm{CB}_{1}\right) ; 23 \mathrm{nM}\left(\mathrm{CB}_{2}\right)$

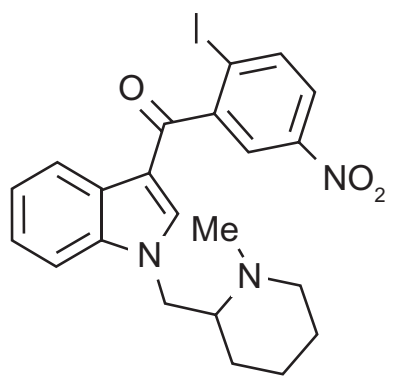

(6) $K_{i}=280 \mathrm{nM}\left(\mathrm{CB}_{1}\right) ; 3.4 \mathrm{nM}\left(\mathrm{CB}_{2}\right)$

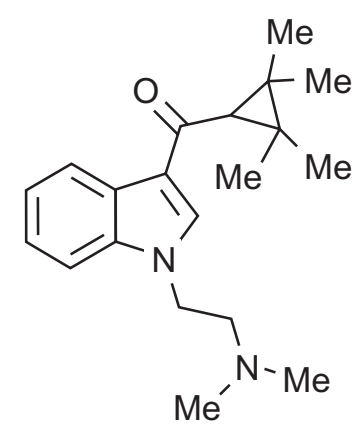

\section{(7) $K_{i}>10,000 \mathrm{nM}\left(\mathrm{CB}_{1}\right) ; 1.9 \mathrm{nM}\left(\mathrm{CB}_{2}\right)$}

Figure 3 Chemical structures of some selective $C_{2}$ receptor modulators. Abbreviations: $\mathrm{CB}$, cannabinoid; $K$, inhibition constant.

CNS side effects. Furthermore, the aminoalkyl indole (Figure 3, compound (7)) was a highly selective $\mathrm{CB}_{2}$ receptor agonist $\left(\mathrm{CB}_{2} K_{i}=1.9 \mathrm{nM} ; \mathrm{CB}_{1} K_{i}>10,000 \mathrm{nM} ; \mathrm{CB}_{1} / \mathrm{CB}_{2}\right.$ selectivity $>5263)$. In another study, Cheng and coworkers developed a novel series of $N$-arylamide oxadiazoles where they identified an amide-linked quinolone derivative (Figure 4, compound (8)) as a potent and selective $\mathrm{CB}_{2}$ agonist $\left(\mathrm{CB}_{2}\right.$ half-maximal effective concentration $\left[\mathrm{EC}_{50}\right]=2.2 \mathrm{nM}$ ) with excellent oral bioavailability profile in rats. ${ }^{37}$ In an elegant study, a research team from GlaxoSmithKline discovered compound GW842166X (Figure 4, compound (9)) based on a pyrimidinecarboxamide template as a clinical candidate to treat inflammatory pain. Compound GW842166X was a selective $\mathrm{CB}_{2}$ receptor agonist $\left(\mathrm{CB}_{2} \mathrm{EC}_{50}=63 \mathrm{nM}\right.$; $\left.\mathrm{CB}_{1} \mathrm{EC}_{50}>30 \mu \mathrm{M}\right)$ and exhibited potent oral activity $\left(\mathrm{ED}_{50}\right.$ [half-maximal effective dose] $=0.1 \mathrm{mg} / \mathrm{kg}$ ) in animal models 
<smiles>Fc1ccc(-c2noc(CCCNc3cnc4ccc(Cl)cc4c3)n2)c(Cl)c1</smiles>

(8) $\mathrm{EC}_{50}=560 \mathrm{nM}\left(\mathrm{CB}_{1}\right) ; 2.2 \mathrm{nM}\left(\mathrm{CB}_{2}\right)$<smiles>Cn1ccc2c(Nc3cccc(Cl)c3)ncc(C(=O)N3CCOCC3)c21</smiles>

(10) $\mathrm{EC}_{50}=6300 \mathrm{nM}\left(\mathrm{CB}_{1}\right) ; 5 \mathrm{nM}\left(\mathrm{CB}_{2}\right)$<smiles>O=C(NCC1CCCCC1)c1cnc(Nc2ccc(Cl)cc2Cl)nc1C(F)(F)F</smiles>

(9) $\mathrm{EC}_{50}>30 \mu \mathrm{M}\left(\mathrm{CB}_{1}\right) ; 63 \mathrm{nM}\left(\mathrm{CB}_{2}\right)$

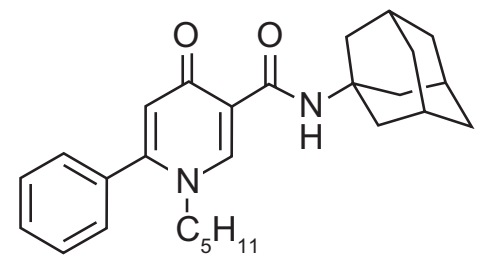

(11) $K_{i}=592 \mathrm{nM}\left(\mathrm{CB}_{1}\right) ; 4.0 \mathrm{nM}\left(\mathrm{CB}_{2}\right)$

Figure 4 Chemical structures of some selective $\mathrm{CB}_{2}$ receptor modulators.

Abbreviations: $\mathrm{CB}$, cannabinoid; $\mathrm{EC}_{50}$, half-maximal effective concentration; $K$, inhibition constant.

of inflammatory pain. Further lead optimization provided the 5-azaindole (Figure 4, compound (10)) with superior $\mathrm{CB}_{2}$ binding affinity $\left(\mathrm{CB}_{2} \mathrm{EC}_{50}=5 \mathrm{nM}\right)$ and efficacy in both acute and chronic pain models. ${ }^{38,39}$ Another study showed that 4-oxo-1,4-dihydropyridines could serve as useful templates to develop selective $\mathrm{CB}_{2}$ receptor ligands. The phenyl-substituted dihydropyridine (Figure 4, compound (11)) exhibited excellent $\mathrm{CB}_{2}$-binding affinity and was an inverse agonist $\left(\mathrm{CB}_{2} K_{i}=4.0 \mathrm{nM} ; \mathrm{CB}_{1} K_{i}=592 \mathrm{nM}\right) \cdot{ }^{40}$ Rapid progress has been made in the development of $\mathrm{CB}_{2}$-selective ligands based on a wide variety of ring templates, and a detailed discussion is beyond the scope of this review. ${ }^{30}$ The evidence acquired to date, clearly supports targeting $\mathrm{CB}_{2}, \mathrm{CB}_{1} / \mathrm{CB}_{2}$, or $\mathrm{CB}_{1}$ receptors and to develop "peripherally restricted" $\mathrm{CB}\left(\mathrm{CB}_{2}\right.$ selective, dual $\mathrm{CB}_{1} / \mathrm{CB}_{2}$ ) agonists that exhibit reduced $\mathrm{CNS}$ side effects as novel agents in the pharmacotherapy of pain disorders.

\section{The TRP channels}

The TRP channel family belongs to ligand-gated and voltagedependent ion channels/nociceptors that respond to chemical, mechanical, or thermal noxious stimuli at the periphery. They are divided into subfamilies. Many are located in the central and peripheral sensory neurons and are potential targets to treat neuropathic pain. ${ }^{41-43}$ The TRPV1 channels have been studied extensively and are known to play a critical role in peripheral sensitization of nociceptors and reduce pain threshold when activated by noxious stimuli. Its expression level is high in sensory neurons. The active ingredient of chili peppers, capsaicin (Figure 5, compound (12)) is a known activator of TRPV1 and is effective as a topical agent to treat pain states. Although opioids are used to treat chronic pain, they exhibit serious side effects such as dizziness, sedation, loss of cognitive function, dependency, respiratory depression, development of tolerance, and constipation. These shortcomings support the need to target novel pathways of pain. In this regard, the role of TRPV1 in peripheral sensitization contributing to acute and chronic pain dictates the need to develop TRPV1 antagonists as potential agents to treat inflammatory and neuropathic pain. ${ }^{44}{ }^{47}$ One of the early TRPV1 antagonists to enter the clinical trial was SB-705498 (Figure 5, compound (13)) based on a pyrrolidine urea that exhibited excellent oral activity in animal models. ${ }^{48}$ Furthermore, Amgen reported the discovery of a clinical candidate AMG517 (Figure 5, compound (14)) based on a oxopyrimidine ring template. Compound AMG517 exhibited excellent TRPV1 inhibition (half-maximal inhibitory concentration $\left[\mathrm{IC}_{50}\right]=0.9 \mathrm{nM}$ ); however, it had a long halflife and low aqueous solubility. Further lead optimization provided compound AMG628 (Figure, compound (15)), the piperazinylpyrimidine derivative that exhibited good TRPV1 inhibition, in vivo half-life, and aqueous solubility and was considered as a clinical candidate. ${ }^{49,50}$ Recently, Abbott Laboratories reported the discovery of an orally active clinical candidate ( $R$ )-1-(5-tert-butyl-2,3-dihydro-1$H$-inden-1-yl)-3-(1H-indazol-4-yl) urea (ABT102, Figure 5, compound (16)) to treat chronic pain. This small molecule exhibited potent TRPV1 binding (TRPV1 $\mathrm{IC}_{50}=4 \mathrm{nM}$ ) and 
<smiles>COc1cc(CNC(=O)CCCCC=C(C)C)ccc1O</smiles>

(12) Capsaicin, TRPV1 $\mathrm{EC}_{50}=0.7 \mu \mathrm{M}$<smiles>O=C(Nc1ccccc1Br)N[C@H]1CCN(c2ccc(C(F)(F)F)cn2)C1</smiles>

(13) SB-705498, TRPV1 IC ${ }_{50}=32 \mathrm{nM}$

$\mathrm{AcHN}$<smiles>Nc1nc2c(Oc3cc(-c4ccc(C(F)(F)F)cc4)ncn3)cccc2s1</smiles>

(14) AMG517, TRPV1 IC s0 $=0.9 \mathrm{nM}$<smiles>CCCCNc1nc2c(Oc3cc(N4CCN([C@H](C)c5ccc(F)cc5)CC4)ncn3)cccc2s1</smiles>

(15) AMG628, TRPV1 IC ${ }_{50}=3.7 \mathrm{nM}$<smiles>CC(C)(C)c1ccc2c(c1)CC[C@H]2NC(=O)Nc1cccc2[nH]ncc12</smiles>

(16) ABT102, TRPV1 IC ${ }_{50}=4 \mathrm{nM}$

Figure 5 Chemical structures of some TRPVI receptor antagonists.

Abbreviations: $\mathrm{EC}_{50}$, half-maximal effective concentration; $I C_{50}$, half-maximal inhibitory concentration; TRPVI, transient receptor potential vanilloid-I.

was effective in various in vivo pain models such as carrageenan induced postoperative and cancer pain. In addition, this agent did not exhibit side effects such as sedation and constipation commonly seen with opiate therapy, highlighting the fact that selective targeting of TRPV1 should provide agents that lack the adverse side effects of opiates. ${ }^{51-53}$ Accordingly, several small-molecule candidates are being developed by the pharmaceutical companies. ${ }^{41,47,54}$ The representative examples discussed here indicate the enormous potential of targeting TRPV1 receptors to treat both acute and chronic pain. Compared with peripherally restricted $\mathrm{CB}$ agonists, TRPV1 receptor modulators reduce pain by acting on both central and peripheral pain pathways, suggesting their potential to cause CNS side effects. The challenges include recognizing TRPV1 gene polymorphism in patients to predict desired therapeutic responses and identify potential side effects such as hyperthermia. ${ }^{46}$

\section{$\mathrm{P} 2 \mathrm{X}$ receptors}

The neurotransmitter ATP (adenosine-5'-triphosphate) is known to produce pain through activating the purinergic receptors $\mathrm{P} 1$ and $\mathrm{P} 2$. The $\mathrm{P} 1$ receptors are known as adenosine receptors, whereas $\mathrm{P} 2$ receptors are further divided into $\mathrm{P} 2 \mathrm{Y}$ (G-protein coupled receptors) and P2X (ligand-gated channels). The $\mathrm{P} 2 \mathrm{X}$ receptors are subdivided into seven receptor subtypes (P2X1, P2X2, P2X3, P2X4, P2X5, P2X6, and $\mathrm{P} 2 \mathrm{X} 7$ respectively) and have attracted widespread attention as potential targets to develop novel pain therapeutics. ${ }^{55-58}$ Among the P2X family, P2X7 is known to be present in immune cells such as monocytes, macrophages, mast cells, lymphocytes, and microglia, indicating their role in disorders such as pain, neurodegeneration, and inflammatory conditions. ${ }^{59,60}$ In this regard, novel $\mathrm{P} 2 \mathrm{X} 7$ receptor antagonists are being developed as clinical candidates to treat acute and chronic pain. ${ }^{61}$ Scientists at Abbott Laboratories reported the development of some distinct small molecules as P2X7 receptor antagonists. In this regard, the 1-benzyl-5-phenyltetrazoles (Figure 6, compound (17)) exhibited potent P2X7 inhibition and were effective in a neuropathic pain model. In another study, a series of $N^{\prime}$-acyl hydrazides was reported as a novel series of $\mathrm{P} 2 \mathrm{X} 7$ receptor antagonists with in vivo activity. Compound (18) shown in Figure 6 was identified as a potent P2X7 receptor antagonist. Further studies led to the development of a novel series of cyanoguanidines with potent P2X7 inhibition, and compound (19) (Figure 6) was effective in a neuropathic pain model. ${ }^{62-64}$ In addition, researchers from AstraZeneca reported the development of adamantine-based small molecules (eg, compound (20) shown in Figure 6) as P2X7 receptor antagonists with ability to prevent the formation of the pro-inflammatory cytokine interleukin-1 $\beta .{ }^{65} \mathrm{~A}$ detailed description of several small-molecule $\mathrm{P} 2 \mathrm{X}$ receptor modulators has been reviewed elsewhere. ${ }^{61,66}$

\section{Targeting glia cells}

Recent studies have focused on the role of non-neuronal cells such as astrocytes and glia or glial cells in pain pathophysiology. Under pathological conditions, glial cells 
<smiles>Clc1cccc(-c2nnnn2Cc2cccnc2)c1Cl</smiles>

(17) hP2X7 $\mathrm{plC}_{50}=6.9$<smiles>O=C(NNc1cccc2ncccc12)C12CC3CC(CC(C3)C1)C2</smiles>

(18) $\mathrm{hP2X7} \mathrm{plC}_{50}=7.99$<smiles>Cc1ncccc1NC(=NC#N)NC(NC(=O)Cc1ccc(Cl)cc1)C(C)(C)C</smiles>

(19) $\mathrm{hP2X7} \mathrm{plC}_{50}=7.5$<smiles>O=C(NCC12CC3CC(CC(C3)C1)C2)c1cc(CN2CCNCC2)ccc1Cl</smiles>

(20) $\mathrm{hP2X7} \mathrm{plC}_{50}=8.0$

Figure 6 Chemical structures of some $\mathrm{P} 2 \mathrm{X} 7$ receptor antagonists.

Abbreviation: $\mathrm{plC}_{50}$, negative logarithm of the half-maximal inhibitory concentration.

get activated and are known to release pro-inflammatory cytokines, chemokines, and other signaling molecules that contribute to neuropathic pain. ${ }^{67-69}$ Some strategies include blocking glial cell activation, prevent the biosynthesis of proinflammatory cytokines, block the action of pro-inflammatory cytokines, and disrupt their signaling. In this regard, the tetracycline antibiotic minocycline (Figure 7, compound (21)) is known to selectively target microglia and could suppress the release of pro-inflammatory cytokines, whereas the xanthine<smiles>CN(C)c1ccc(O)c2c1C[C@H]1CC3=C(O)[C@@]4(O)C(=O)C(C(N)=O)=C(O)[C@@H](N(C)C)[C@]4(C)C3C(=O)C21</smiles>

(21) Minocycline<smiles>CC(=O)CCCCn1c(=O)c2c(ncn2C)n(C)c1=O</smiles>

(22) Pentoxifylline

Figure 7 Chemical structures of some glial cell modulators. derivative pentoxyfylline $\left(\operatorname{Trental}^{\circledR}\right.$, Aventis, Strasbourg, France) (Figure 7, compound (22)) currently used to treat chronic occlusive arterial disease and AV411 (Ketas ${ }^{\mathrm{TM}}$, Senju Pharmaceutical Co, Osaka, Japan) are known to inhibit proinflammatory cytokine biosynthesis. These small molecules are able to cross the blood-brain barrier, indicating their potential to target neuropathic pain. In contrast, biological molecules such as etanercept (Enbrel ${ }^{\circledR}$, Amgen, Thousand Oaks, CA) and the interleukin-1 $\beta$ antagonist anakinra $\left(\right.$ Kineret $^{\circledR}$, Amgen) are known to exhibit efficacy in neuropathic animal models, suggesting their ability to block glial cell mediated cytokine signaling. ${ }^{68}$ However, these agents are injectables that exhibit poor CNS penetration. In the last decade, glial cells have emerged as attractive targets to prevent chronic pain..$^{70,71}$ In this regard, the neuroprotective nature of glial cells during tissue injury suggests a careful approach toward developing novel glial cell modulators. The molecular mechanisms of glial cell activation and its consequences is still a work in progress.

\section{Conclusion}

The last decade has seen an unprecedented surge in understanding the complexity of pain pathology. The identification of novel pain targets such as $\mathrm{CB}$ receptors, FAAH, voltage- and ligand-gated ion channels (sodium channels, T-type calcium channels, P2X receptors, TRP channels), peptide receptor antagonists, NGF and glial cell modulators to treat nociceptive, inflammatory, and neuropathic pain is highly promising. Preclinical data shows that one can develop 
peripherally restricted agents such as $\mathrm{CB}$ receptor modulators and FAAH inhibitors that do not exhibit psychotropic effects indicating their superior side-effect profile compared with traditional pain therapies. The challenge is to prove the efficacy seen in preclinical data of novel agents with clinical evidence. The benefit-to-risk ratios of novel pain therapies will come under careful scrutiny of regulatory agencies. Despite the challenges ahead, it is clear that understanding the molecular mechanisms of novel pain targets will go a long way in developing selective or "site specific" agents that exhibit efficacy and superior side-effect profile as pain therapeutics.

\section{Acknowledgments}

The authors would like to thank the School of Pharmacy and Faculty of Science at the University of Waterloo for supporting the research work.

\section{Disclosure}

The authors have no conflicts of interest with the current work and received no payment for the preparation of this manuscript.

\section{References}

1. Anand KJS, Craig KD. New perspectives on the definition of pain. Pain. 1996;67(1):3-6.

2. Melnikova I. Pain market. Nat Rev Drug Dis. 2010;9(8):589-590.

3. Tsang A, Von Korff M, Lee S, et al. Common chronic pain conditions in developed and developing countries: gender and age differences and comorbidity with depression-anxiety disorders. J Pain. 2008; 9(10):883-891.

4. Goucke RC. The management of persistent pain. Med J Aust. 2003; 178(9):444-447.

5. Helms JE, Barone CP. Physiology and treatment of pain. Crit Care Nurse. 2008;28(6):38-49.

6. Reichling DB, Levine JD. Pain and death: neurodegenerative disease mechanisms in the nociceptor. Ann Neurol. 2011;69(1):13-21.

7. Baron R. Neuropathic pain: a clinical perspective. Handb Exp Pharmacol. 2009;194:3-30.

8. Voscopoulos C, Lema M. When does acute pain become chronic? $\mathrm{Br}$ J Anaesth. 2010;105(Suppl 1):i69-i85.

9. Milan MJ. The induction of pain: an integrative review. Prog Neurobiol. 1999;57(1):1-164.

10. Schaible HG. Peripheral and central mechanisms of pain generation. Handb Exp Pharmacol. 2007;177:3-28.

11. Scholz J, Woolf CJ. Can we conquer pain? Nat Neurosci. 2002;5(Suppl): 1062-1067.

12. Bras M, Dordevic V, Grequrek R, Bulajic M. Neurobiological and clinical relationship between psychiatric disorders and chronic pain. Psychiatr Danub. 2010;22(2):221-226.

13. Marazziti D, Mungai F, Vivarelli L, Presta S, Dell'Osso B. Pain and psychiatry: a critical analysis and pharmacological review. Clin Pract Epidemiol Ment Health. 2006;2:31.

14. Lynch ME, Watson CPN. The pharmacotherapy of chronic pain: a review. Pain Res Manage. 2006;11(1):11-38.

15. Kroenke K, Krebs EE, Bair MJ. Pharmacotherapy of chronic pain: a synthesis of recommendations from systematic reviews. Gen Hosp Psychiatry. 2009;31(3):206-219.
16. Centers for Disease Control and Prevention. National Hospital Ambulatory Medical Care Survey (NHAMCS). Atlanta, GA: Centers for Disease Control and Prevention. Available from: http:/www.cdc. gov/nchs/ahcd.htm. Accessed June 18, 2011.

17. Woodcock J. A difficult balance - pain management, drug safety, and the FDA. N Eng J Med. 2009;361(22):2105-2107.

18. Trelle S, Reichenbach S, Wandel S, et al. Cardiovascular safety of nonsteroidal anti-inflammatory drugs: network meta-analysis. BMJ. 2011; 342:c7086.

19. Mendelson J, Flower K, Pletcher MJ, Galloway GP. Addiction to prescription opioids: characteristics of the emerging epidemic and treatment with buprenorphine. Exp Clin Psychopharmacol. 2008;16(5): 435-441.

20. Fox A, Bevan S. Therapeutic potential of cannabinoid receptor agonists as analgesic agents. Expert Opin Investig Drugs. 2005;14(6): 695-703.

21. Pertwee RG. Cannabinoid receptors and pain. Prog Neurobiol. 2001; 63(5):569-611.

22. Cheng Y, Hitchcock SA. Targeting cannabinoid agonists for inflammatory and neuropathic pain. Expert Opin Investig Drugs. 2007;16(7):951-965.

23. Galieque S, Mary S, Marchand J, et al. Expression of central and peripheral cannabinoid receptors in human immune tissues and leukocyte subpopulations. Eur J Biochem. 1995;232(1):54-61.

24. Curran HV, Brignell C, Fletcher S, Middleton P, Henry J. Cognitive, subjective dose-response effects of acute oral $\Delta^{9}$-tetrahydrocannabinol (THC) in infrequent cannabis users. Psychopharmacology. 2002;164(1):61-70.

25. Robinson L, Goonawardena AV, Pertwee RG, Hampson RE, Riedel G. The synthetic cannabinoid HU210 induces spatial memory deficits and suppresses hippocampal firing rate in rats. Br J Pharmacol. 2007;151(5): $688-700$.

26. Herkenham M, Lynn AB, Johnson MR, Melvin LS, de Costa BR, Rice KC. Characterization and localization of cannabinoid receptors in rat brain: a quantitative in vitro autoradiographic study. J Neurosci. 1991;11(2):563-583.

27. Devane WA, Hanus L, Breuer A, et al. Isolation and structure of a brain constituent that binds to the cannabinoid receptor. Science. 1992;258(5090):1946-1949.

28. Pertwee RG. Pharmacological actions of cannabinoids. Handb Exp Pharmacol. 2005;168:1-51.

29. Rahn EJ, Hohman AG. Cannabinoids as pharmacotherapies for neuropathic pain: from the bench to the bedside. Neurotheraptics. 2009;6(4):713-737.

30. Thakur GA, Tichkule R, Bajaj S, Makriyannis A. Latest advances in cannabinoid receptor agonists. Expert Opin Ther Patents. 2009;19(12): 1647-1673.

31. Hsieh GC, Pai M, Chandran P, et al. Central and peripheral sites of action for $\mathrm{CB}_{2}$ receptor mediated analgesic activity in chronic inflammatory and neuropathic pain models in rats. $\mathrm{Br} J$ Pharmacol. 2011;162(2):428-440.

32. Hanus L, Breuer A, Tchillibon S, et al. HU-308: a specific agonist for $\mathrm{CB}_{2}$, a peripheral cannabinoid receptor. Proc Natl Acad Sci U S A. 1999;96(25):14228-14233.

33. Yao BB, Mukherjee S, Fan Y, et al. In vitro pharmacological characterization of AM1241: a protean agonist at the cannabinoid $\mathrm{CB}_{2}$ receptor? Br J Pharmacol. 2006;149(2):145-154.

34. Ibrahim MM, Deng $\mathrm{H}$, Zvonok $\mathrm{A}$, et al. Activation of $\mathrm{CB}_{2}$-cannabinoid receptors by AM1241 inhibits experimental neuropathic pain: pain inhibition by receptors not present in the CNS. Proc Natl Acad Sci US A. 2003;100(18):10529-10533.

35. Frost M, Dart MJ, Tietje KR, et al. Indol-3-ylcycloalkyl ketones: effects of $\mathrm{N} 1$ substituted indole side chain variations on $\mathrm{CB}_{2}$ cannabinoid receptor activity. J Med Chem. 2010;53(1):295-315.

36. Frost JM, Dart MJ, Tietje KR, et al. Indol-3-yl-tetramethylcyclopropyl ketones: effects of indole ring substitution on $\mathrm{CB}_{2}$ cannabinoid receptor activity. J Med Chem. 2008;51(6):1904-1912. 
37. Cheng Y, Albrecht BK, Brown B, et al. Discovery and optimization of a novel series of $\mathrm{N}$-arylamide oxadiazoles as potent, highly selective and orally bioavailable cannabinoid receptor $2\left(\mathrm{CB}_{2}\right)$ agonists. $J \mathrm{Med}$ Chem. 2008;51(16):5019-5034.

38. Giblin GMP, O'Shaughnessy CT, Naylor A, et al. Discovery of 2-[(2,4-dichlorophenyl)amino]- $N$-[(tetrahydro-2 $H$-pyran-4-yl)methyl]4-(trifluoromethyl)-5-pyrimidinecarboxamide, a selective $\mathrm{CB} 2$ receptor agonist for the treatment of inflammatory pain. $J$ Med Chem. 2007; 50(11):2597-2600.

39. Giblin GMP, Billinton A, Briggs M, et al. Discovery of 1-[4-(3chlorophenylamino)-1-methyl-1H-pyrrolo[3,2-c]pyridin-7-yl]1-morpholin-4-ylmethanone (GSK554418A), a brain penetrant 5-azaindole $\mathrm{CB}_{2}$ agonist for the treatment of chronic pain. J Med Chem. 2009;52(19):5785-5788.

40. El Bakali J, Muccioli GG, Renault N, et al. 4-Oxo-1,4-dihydropyridines as selective $\mathrm{CB}_{2}$ Cannabinoid receptor ligands: structural insights into the design of a novel inverse agonist series. J Med Chem. 2010; 53(22):7918-7931.

41. Patapoutian A, Tate S, Woolf CJ. Transient receptor potential channels: targeting pain at the source. Nat Rev Drug Dis. 2009;8(1):55-68.

42. Romanovsky AA, Almeida MC, Garami A, et al. The transient receptor potential vanilloid-1 channel in thermoregulation: thermosensor it is not. Pharmacol Rev. 2009;61(3):228-261.

43. Venkatachalam K, Montell C. TRP channels. Annu Rev Biochem. 2007;76:387-417.

44. Levine JD, Haber NA. TRP channels: targets for the relief of pain. Biochim Biophys Acta. 2007;1772(8):989-1003.

45. Premkumar LS. Targeting TRPV1 as an alternative approach to narcotic analgesic to treat chronic pain conditions. AAPS J. 2010;12(3):361-370.

46. Joshi NK, Szallasi A. TRPV1 antagonists: the challenges for therapeutic targeting. Trends Mol Med. 2009;15(1):14-22.

47. Gunthorpe MJ, Chizh BA. Clinical development of TRPV1 antagonists: targeting a pivotal point in the pain pathway. Drug Discov Today. 2009;14(1-2):56-67.

48. Rami HK, Thompson M, Stemp G, et al. Discovery of SB-705498: a potent, selective and orally bioavailable TRPV1 antagonist suitable for clinical development. Bioorg Med Chem Lett. 2006;16(12): 3287-3291.

49. Doherty EM, Bannon AW, Bo Y, et al. Novel vanilloid receptor-1 antagonists: 2. Structure-activity relationship of 4-oxopyrimidines leading to the selection of a clinical candidate. J Med Chem. 2007;50(15): 3515-3527.

50. Wang HL, Katon J, Balan C, et al. Novel vanilloid receptor-1 antagonists: 3 . The identification of a second-generation clinical candidate with improved physicochemical and pharmacokinetic properties. JMed Chem. 2007;50(15):3528-3539.

51. Gomtsyan A, Bayburt EK, Schmidt RG, et al. Identification of $(R)-1$ (5-tert-butyl-2,3-dihydro- $1 H$-inden-1-yl)-3-(1H-indazol-4-yl) urea (ABT-102) as a potent TRPV1 antagonist for pain management. J Med Chem. 2008;51(3):392-395.
52. Honore P, Chandran P, Hernandez G, et al. Repeated dosing of ABT-102, a potent and selective TRPV1 antagonist, enhances TRPV1-mediated analgesic activity in rodents, but attenuates antagonist-induced hyperthermia. Pain. 2009;142(1-2):27-35.

53. Rowbotham MC, Nothaft W, Duan WR, et al. Oral and cutaneous thermosensory profile of selective TRPV1 inhibition by ABT-102 in a randomized healthy volunteer trial. Pain. 2011;152(5):1192-2000.

54. Westaway SM. The potential of transient receptor potential vanilloid type 1 channel modulators for the treatment of pain. J Med Chem. 2007;50(11):2589-2596.

55. Chizh BA, Illes P. P2X receptors and nociception. Pharmacol Rev. 2001;53(4):553-568.

56. Kennedy C, Assis TS, Currie J, Rowan EG. Crossing the pain barrier: P2 receptors as targets for novel analgesics. J Physiol. 2003;553(Pt 3):683-694.

57. Kennedy C. P2X receptors: targets for novel analgesics? Neuroscientist. 2005;11(4):345-356.

58. Burnstock G. Purinergic signaling and disorders of the central nervous system. Nat Rev Drug Dis. 2008;7(8):575-590.

59. Surprenant A, North RA. Signaling at purinergic P2X receptors. Annu Rev Physiol. 2009;71:333-359.

60. Hughes JP, Hatcher JP, Chessell IP. The role of $\mathrm{P}_{2} \mathrm{X}_{7}$ in pain and inflammation. Purinergic Signal. 2007;3(1-2):163-169.

61. Gunosewoyo H, Kassiou M. P2X purinergic receptor ligands: recently patented compounds. Expert Opin Ther Pat. 2010;20(5):625-646.

62. Nelson DW, Gregg RJ, Kort ME, et al. Structure-activity relationship studies on a series of novel, substituted 1-benzyl-5-phenyltetrazole P2X7 antagonists. J Med Chem. 2006;49(12):3659-3666.

63. Nelson DW, Sarris K, Kalvin DM, et al. Structure-activity relationship studies on $\mathrm{N}^{\prime}$-aryl carbohydrazide P2X7 antagonists. J Med Chem. 2008;51(10):3030-3034.

64. Medrano AP, Donnelly-Roberts DL, Honore P, et al. Discovery and biological evaluation of novel cyanoguanidine P2X7 antagonists with analgesic activity in a rat model of neuropathic pain. $J$ Med Chem. 2009;52(10):3366-3376.

65. Furber M, Alcaraz L, Bent JE, et al. Discovery of potent and selective adamantane-based small-molecule P2X7 receptor antagonists/ interleukin-1 $\beta$ inhibitors. J Med Chem. 2007;50(24):5882-5885.

66. Guile SD, Alcaraz L, Birkinshaw TN, et al. Antagonists of the P2X7 receptor. From lead identification to drug development. J Med Chem. 2009;52(10):3123-3141.

67. Watkins LR, Maier SF. Targeting glia to control clinical pain: an idea whose time has come. Drug Discov Today. 2004;1(1):83-88.

68. Milligan ED, Watkins LR. Pathological and protective roles of glia in chronic pain. Nat Rev Neurosci. 2009;10(1):23-36.

69. McMahon SB, Malcangio M. Current challenges in glia-pain biology. Neuron. 2009;64(1):46-54.

70. Svensson CI, Brodin E. Spinal astrocytes in pain processing: nonneuronal cells as therapeutic targets. Mol Interv. 2010;10(1):25-38.

71. Beggs S, Salter MW. Microglia-neuronal signaling in neuropathic pain hypersensitivity 2.0. Curr Opin Neurobiol. 2010;20(4):474-480.
Journal of Pain Research

\section{Publish your work in this journal}

The Journal of Pain Research is an international, peer-reviewed, open access, online journal that welcomes laboratory and clinical findings in the fields of pain research and the prevention and management of pain. Original research, reviews, symposium reports, hypothesis formation and commentaries are all considered for publication.

\section{Dovepress}

The manuscript management system is completely online and includes a very quick and fair peer-review system, which is all easy to use. Visit http://www.dovepress.com/testimonials.php to read real quotes from published authors. 